\title{
Molecular Mechanisms of Floral Boundary Formation in Arabidopsis
}

\author{
Hongyang $\mathrm{Yu}^{1,2}$ and Tengbo Huang ${ }^{1, *}$ \\ 1 College of Life Sciences and Oceanography, Shenzhen University, 3688 Nanhai Ave., Shenzhen 518060, \\ China; hongyangyu@szu.edu.cn \\ 2 Key Laboratory of Optoelectronic Devices and Systems of Ministry of Education and Guangdong Province, \\ College of Optoelectronic Engineering, Shenzhen University, 3688 Nanhai Ave., Shenzhen 518060, China \\ * Correspondence: tengbohuang@szu.edu.cn; Tel.: +86-755-2653-5130
}

Academic Editor: Jianhua Zhu

Received: 6 February 2016; Accepted: 23 February 2016; Published: 2 March 2016

\begin{abstract}
Boundary formation is a crucial developmental process in plant organogenesis. Boundaries separate cells with distinct identities and act as organizing centers to control the development of adjacent organs. In flower development, initiation of floral primordia requires the formation of the meristem-to-organ $(\mathrm{M}-\mathrm{O})$ boundaries and floral organ development depends on the establishment of organ-to-organ $(\mathrm{O}-\mathrm{O})$ boundaries. Studies in this field have revealed a suite of genes and regulatory pathways controlling floral boundary formation. Many of these genes are transcription factors that interact with phytohormone pathways. This review will focus on the functions and interactions of the genes that play important roles in the floral boundaries and discuss the molecular mechanisms that integrate these regulatory pathways to control the floral boundary formation.
\end{abstract}

Keywords: Arabidopsis; floral boundary; regulatory pathway; transcription factor; phytohormones

\section{Introduction}

Organ boundaries are groups of specialized cells with restricted growth that are crucial for the development of plants and animals. Boundaries delineate identities by separating distinct functional domains, such as the meristem and organ primordia or adjacent organs, and also function as organizing centers for the downstream signaling events to pattern the organs at later stages [1,2]. Recent studies have uncovered a suite of important genes and pathways that establish and maintain organ boundaries in plant development [2-4]. A number of these genes have conserved functions in defining the boundaries of various organs, while others play more specialized roles in a certain patterning events, suggesting a complex regulatory network controlling boundary formation in plants [5-9].

As a key structure of flowering plants, the development of floral organs has been extensively studied $[10,11]$. Similar to other lateral organs, floral primordia initiate from the shoot apical meristem (SAM) and undergo a complex organogenesis process that incorporates finely controlled cell division, expansion and differentiation [12,13]. Establishment of boundaries is a critical step in floral organogenesis; this includes the formation of boundaries between the meristem and floral organs (the meristem-to-organ boundary; $\mathrm{M}-\mathrm{O}$ boundary), as well as the boundaries between adjacent floral organs (the organ-to-organ boundary; $\mathrm{O}-\mathrm{O}$ boundary) $[2,3,14]$. These boundary regions express a suite of genes with either general or floral-specific functions to define the boundary field and influence the developmental programs of the adjacent floral tissues. Here, we will review the recent advances in the regulation of the floral boundaries in the model species Arabidopsis thaliana, particularly the key molecular mechanisms that play specific roles during flower development (as summarized in Figure 1). We will also discuss how these central regulators interact with the internal phytohormone signals to fine-tune the boundary formation in flowers. 
A

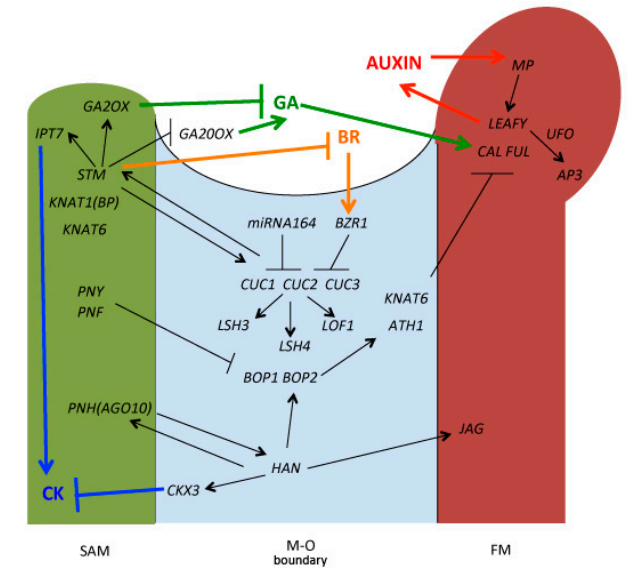

B

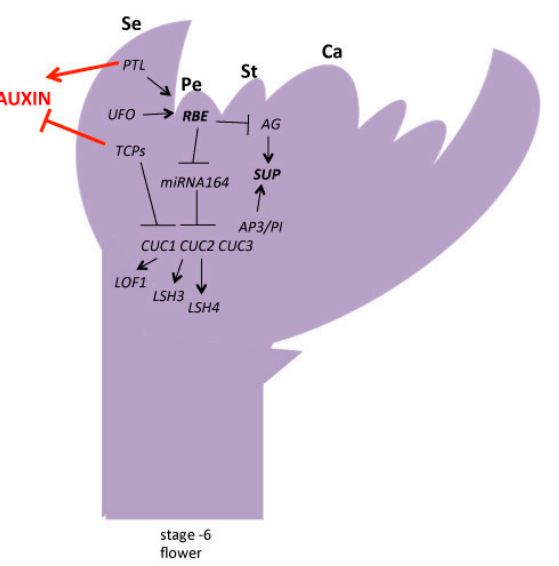

Figure 1. Gene network regulating floral boundaries. (A) Major regulatory pathways controlling floral $\mathrm{M}-\mathrm{O}$ boundaries. Shoot apical meristem is demonstrated in green, $\mathrm{M}-\mathrm{O}$ boundary is demonstrated in light blue and floral meristem (FM) is demonstrated in brown; (B) Key pathways regulating floral $\mathrm{O}-\mathrm{O}$ boundaries shown in a stage 6 flower. Black arrows and bars represent the positive and negative genetic interactions. Color arrows and bars represent the promoting and repressing controls between genes and phytohormones. Pathways related to the action of phytohormones are indicated as red: auxin; green: Gibberellins (GA); blue: Cytokinins (CK); and orange: Brassinosteroids (BR). In the stage 6 flower, regulatory pathways associated with two floral-specific zinc-finger transcription factors, $R B E$ and SUP, are highlighted. Se: sepal; Pe: petal; St: stamen; Ca: carpel.

\section{Regulation of the Meristem-Organ (M-O) Boundary Formation in the Flower Development}

The Arabidopsis shoot apical meristem (SAM) consists of a central zone that stem cells reside in, a peripheral zone that gives rise to organ primordia and a rib zone that forms vascular and interior stem structures [15]. In the reproductive stages, the SAM is converted to an inflorescence meristem where floral meristems arise and further develop to mature flowers [11,16]. In this process, key transcription regulators LEAFY (LFY) and APETALA1 (AP1) play a crucial role. These floral identity genes are upregulated in response to floral inductive signals, such as the FLOWERING LOCUS T (FT) pathways, and in turn elicit flowering [11,17-19]. Initiation of flowers also requires the formation of the $\mathrm{M}-\mathrm{O}$ boundary that separates the central zone and peripheral zone in the inflorescence meristem $[20,21]$. This process is closely related to the local depletion of phytohormone auxin that causes the lower division and growth rate of the M-O boundary cells [2,22]. Consistent with this model, mutants in the auxin efflux transporter gene PINFORMED1 (PIN1) or in the auxin-responsive transcription factor MONOPTEROS (MP) have naked, "flowerless" inflorescence that is associated with the misexpression of key meristem and organ boundary regulators in the peripheral zone, including SHOOT MERISTEMLESS (STM), LEAFY (LFY), and CUP-SHAPED COTYLEDON (CUC) genes [16,23-26]. STM is a member of the class I KNOTTED1-like (KNOX) genes in the three-amino acid loop extension (TALE) homeodomain protein family and CUC genes (CUC1, CUC2 and CUC3) are NAC family transcription factors [5-7,27]. STM and the CUC genes are key regulators of meristem and organ boundary development, and play a pivotal role at both vegetative and reproductive stages [28]. CUC1 and CUC2 are expressed in the organ boundaries and activate STM for meristem initiation $[5,29]$. STM in turn maintains the expression of CUC genes in the boundary domains for organ separation; this is likely through the direct regulation of CUC1 and indirect regulation of CUC2 and CUC3 [28].

Other KNOX genes, such as BREVIPEDICELLUS (BP)/KNAT1 and KNAT6, are also involved in the initiation and maintenance of SAM and organ boundaries in collaboration with STM [30,31]. KNOX genes specify meristem and boundary domains in part by modulating the abundance of phytohormones including cytokinins (CK), gibberellins (GA) and brassinosteroids (BR). Maintenance of meristem identity is associated with a high CK to low GA ratio that sustains cell division and 
inhibits cell differentiation. KNOX genes promote CK levels by activating the CK biosynthetic gene ISOPENTENYL TRANSFERASE7 (IPT7) [32,33], and reduce GA levels by positively regulating GA catabolic GA2-oxidases [34] and negatively regulating GA biosynthetic GA20-oxidases [35]. Brassinosteroids (BR) also play a key role in the formation of organ boundaries. BR-activated BRASSINAZOLE-RESISTANT1 (BZR1) directly represses the expression of CUC genes, and lower levels of BZR1 were observed in the boundary cells [36]. Recent studies in rice showed that KNOX genes down regulate $B R$ signaling in the meristem by direct activation of BR catabolic genes to maintain the SAM activity [37].

These regulatory pathways suggest that a complex interaction between phytohormones and CUC/KNOX genes controls meristem and boundary formation. These pathways act recurrently at both vegetative and reproductive stages, indicating their conserved roles in the plant life cycle. Conversely, the flower-inducing gene $L F Y$ specifically regulates organ development in the reproductive phase [19,38]. Auxin signal affects $L F Y$ through the direct activation of $L F Y$ by $M P$ [39]. MP directly activates $L F Y$ in response to auxin only in the reproductive phase, suggesting a specific molecular function of auxin signaling in reproductive development [39]. LFY also directly regulates auxin pathways, which forms a forward-loop to reinforce this relationship [39,40]. In addition to the auxin-associated pathways, $L F Y$ also regulates flower initiation in response to PENNYWISE (PNY) and POUND-FOOLISH (PNF), two BELL-like genes that belong to the same TALE homeodomain-protein family as KNOX genes [41-43]. Double mutant pny pnf plants do not produce flowers, which is largely due to the overexpression of lateral organ boundary genes BLADE-ON-PETIOLE1/2 (BOP1/2), as well as their downstream genes KNAT6 and ARABIDOPSIS THALIANA HOMEOBOX GENE1 (ATH1) that also encode TALE homeodomain proteins [44]. The BOP1/2-KNAT6/ATH1 module blocks flowering via a series of pathways that involves phytohormones Jasmonic acid (JA) and Gibberellins (GA), as well as the microRNA156-SPL and-miR172 regulation, to finally effect $L F Y$ and the other two flower-inducing genes CAULIFLOWER (CAL) and FRUITFUL (FUL) [44,45]. Upon flowering, PNY and PNF negatively regulate $B O P 1 / 2$ and KNAT6/ATH1, which in turn activates $L F Y, C A L$ and FUL to induce the initiation of flowers [44].

While $L F Y$ is controlled through boundary-related pathways, it also functions in collaboration with other boundary-regulating genes, such as the F-box protein UNSUAL FLORAL ORGANS (UFO). UFO is specifically expressed in the boundary domain surrounding the STM-expressing cells at early floral stages [46,47]. Mutants of UFO display a variety of defects including delayed floral meristem development; reduced growth or absence of petals and stamens; and fused floral organs, suggesting a critical role of UFO in the regulation of meristem, lateral boundary and organ formation at reproductive stages [48-50]. A physical interaction between UFO and LFY recruits the LFY-UFO complex to the promoter of the B-function floral homeotic gene APETALA3 (AP3), and thus activates AP3 to specify the identity of petals and stamens during flower development [51].

Another key regulator of the floral M-O boundary is the GATA-3 transcriptional factor HANABA TARANU (HAN) [52,53]. HAN is specifically expressed at the floral M-O boundaries and interacts with both the meristem-regulating gene ARGONAUTE 10/PINHEAD (PNH), a founding member of the ARGONAUTE family that acts in small RNA pathways [54-56], and the genes required for organ primordia development, including BOP2 and JAGGED (JAG), a $\mathrm{C} 2 \mathrm{H} 2$ zinc finger transcriptional factor that promotes cell division and growth of lateral organs $[53,57,58]$. These interactions promote the functions of both meristem and organ primordia-specific genes to delineate these two distinct domains in the shoot apex. In addition, HAN also directly activates CYTOKININ OXIDASE 3 (CKX3) to reduce cytokinin levels, which in turn suppresses cell division activity and maintains the $\mathrm{M}-\mathrm{O}$ boundary [53]. These combined effects suggest that HAN plays a pivotal role in the $\mathrm{M}-\mathrm{O}$ boundary to facilitate communication with the meristem and organ primordia.

\section{Controlling the Establishment of the Floral Organ-Organ (O-O) Boundary}

The Arabidopsis flower contains sepals, petals, stamens and carpels arranged in four concentric whorls [11]. Flower development requires the formation of correct $\mathrm{O}-\mathrm{O}$ boundaries that function to 
separate adjacent whorls (interwhorl boundaries) and adjacent organs within a whorl (intrawhorl boundaries) [14].

Many genes that establish $\mathrm{M}-\mathrm{O}$ boundaries also set floral $\mathrm{O}-\mathrm{O}$ boundaries, such as BOP1/2 [59,60], HAN [52,53] and CUC genes [5-7]. Among these genes, CUCs are probably the earliest ones reported to be implicated in the floral O-O boundary formation. CUC1, CUC2 and CUC3 are all expressed in the floral organ primordia and boundaries, and the double mutant combinations of the three CUC genes form fusions between adjacent floral organs [5,6,61]. More importantly, CUC genes are key nodes of the genetic network that regulates floral organ boundaries. They act to control a suite of boundary-regulating genes, including ORGAN BOUNDARY1 (OBO1, also LIGHT-DEPENDENT SHORT HYPOCOTYLS3, LSH3) and LSH4 that are members of the ALOG family [62,63], and the Myb-domain transcription factor LOF1 [36]. CUC genes also function downstream of important organ boundary and growth regulators, such as the TEOSINTE BRANCHED1, CYCLOIDEA, and PCF (TCP) transcription factors $[64,65]$ and BZR1 involved in the brassinosteroids (BR) signaling [36].

CUC1 and CUC2 are post-transcriptionally regulated by microRNA 164 that is transcribed from three loci: MIR164a, MIR164b and MIR164c [66-69]. One of the three miRNA164 primary genes, MIR164c (also named EARLY EXTRA PETALS 1; EEP1) plays a floral specific role in petal organogenesis. The mutant in $M I R 164 \mathrm{c}$ has extra petals in early-arising flowers that were proposed to be associated with the additional boundary domains formed in the second whorl [67].

The petal-specific function of EEP1 is controlled in part by the $\mathrm{C} 2 \mathrm{H} 2$ zinc finger transcription factor RABITT EARS (RBE) [8]. RBE is specifically expressed in petal primordia and negatively regulates the expression of $M I R 164 c$ by directly interacting with its promoter region [8]. The rbe mutants exhibit aberrant or absence of petals, and these phenotypes are partly or completely rescued by eep1, supporting the model that MIR164c acts as a key downstream effector of RBE in petal organogenesis [8]. RBE also functions non-autonomously in the regulation of sepal boundaries. The fused sepal phenotype in the rbe mutant could also be inhibited by eep 1 and enhanced by cuc1 and 2, indicating the miR164-CUC pathway might be involved in the RBE-mediated sepal boundary formation as well [8]. In addition to its regulation of the intra-whorl $\mathrm{O}-\mathrm{O}$ boundaries, $R B E$ also sets the boundary between the second and third whorl by restricting the spatial expression of AGAMOUS $(A G)$, a C-function floral homeotic gene that specifies the identity of stamens and carpels [70]. Another floral organ boundary gene UFO seems to act upstream of $R B E$ to promote this process, as in the $u f o-11$ mutant, $R B E$ expression is dramatically down-regulated, while $A G$ is ectopically expressed [70].

Besides UFO, the tri-helix transcripton factor PETAL LOSS (PTL) also regulates RBE. PTL is specifically expressed in the inter-sepal zone and acts in concert with CUC1 and CUC2 in the formation of sepal boundaries [9]. Interestingly, PTL also controls petal organogenesis in the same pathway with $R B E$, even though PTL is not expressed in the petals [71,72]. The regulation of PTL on petal organogenesis might be dependent on an interwhorl mobile signal that involves the phytohormone auxin [72], which suggests that the inter-sepal boundary may influence the organ development in the adjacent floral whorl.

Floral organ fusions were also observed in the mutant of F-box gene HAWAIIAN SKIRT (HWS) [73], which was first reported as the fused floral organs 1 (ffo1) locus in the Landsberg background [73,74]. The loss-of-function hws-1 resulted in floral organ fusions within a specific whorl (fused sepals and stamens) and also between adjacent whorls (fusion between the third and fourth whorl) [73]. HWS may act with UFO to regulate organ initiation in the early stages of flower development, as no floral organs were generated in the hws ufo double mutant plant [74]. The direct targets of HWS are still unknown, but because it encodes an F-box protein, it was proposed that HWS might function to degrade growth regulating genes such as those involved in auxin functions [73].

Another floral-specific $\mathrm{O}-\mathrm{O}$ boundary-regulating gene is SUPERMAN (SUP), which encodes a $\mathrm{C} 2 \mathrm{H} 2$ zinc finger gene closely related to $R B E[75,76]$. SUP plays a key role in the establishment of the boundary between the third and fourth floral whorl. Disruption of this boundary in the sup mutant leads to the ectopic expression of AP3 that promotes the formation of extra stamens in 
the fourth whorl $[75,76]$. The boundary-specific function of SUP is controlled by important floral regulators, including LFY, AP3, PISTILATA (PI) and AG [77], and SUP controls cell proliferations of organ primordia in the third and fourth whorl, in part via regulating auxin and CK-signalling pathways [78]. These interactions suggest that SUP is a central gene in the regulatory network of the stamen-carpel boundary that integrates key transcription factors and hormonal regulators of floral organ development.

\section{Conclusions and Perspectives}

The establishment of floral boundaries is critical for the maintenance of inflorescence meristems and the formation of floral organs. Many genes and pathways regulate floral $\mathrm{M}-\mathrm{O}$ and $\mathrm{O}-\mathrm{O}$ boundaries; some of them appear to have functions in both vegetative and reproductive development, while others play a more floral-specific role. How these different types of regulators interact in floral boundary formation is one of the important questions that remain to be well understood. Furthermore, many of these boundary genes encode transcription factors or co-factors, suggesting that transcriptomic approaches, such as high-throughput RNA-sequencing and chromatin Immunoprecipiation combined with high-throughput sequencing (ChIP-seq), could unravel the genetic network regulated by these key regulators [79]. In addition, many floral boundary genes function in post-transcriptional regulation, such as the F-box family members. Proteomic studies including yeast-two hybrid screening and co-immunoprecipitation followed by protein-sequencing would be more suitable for identifying the substrates and interacting genes of these post-transcriptional regulators [80-82]. A recent study combining boundary-specific gene expression analysis and a genome-wide protein-DNA interaction assay generated an organ boundary-enriched transcriptional network in the Arabidopsis leaf development [83]. A similar approach could also be applied in flowers to uncover the pathways that function specifically in floral boundary formation. By comparing the results of these experiments, we could generate a list of common regulators in the overlaps of these datasets. These common genes or pathways likely play pivotal roles in the floral organ boundaries and the relationships of these regulators can form a comprehensive network that explains the molecular mechanism of floral organ boundary formation.

It is also worth noting that a number of the floral boundary regulators crosstalk with phytohormone pathways $[2,36,39,84,85]$. Techniques for characterizing the biogenesis, transport and response of phytohormones have been largely improved in the past years $[86,87]$. For instance, the DR5-GUS and DII-VENUS systems applied a visualized auxin sensor in the investigation of the response to auxin $[88,89]$. Florescent reporters were also employed in the analysis of GA and BR in plants [90,91]. Application of these molecular tools in boundary-specific assays will help elucidate the spatial and temporal regulation of phytohormone signaling in the boundary field and better understand how hormonal pathways and other boundary regulators are coordinated in the formation of floral boundaries. We expect that the integration of the information from all these approaches will provide us with a complex regulatory map that not only shows the details of gene functions and interactions in the floral boundaries, but also directs us to further explore the novel molecular mechanisms underlining the boundary formation in flower development.

Acknowledgments: We thank Adam Saffer (Vivian Irish lab, Yale University) for valuable comments on the manuscript. Research in the Huang Lab is supported by the National Natural Science Foundation of China (31571252).

Author Contributions: Hongyang Yu and Tengbo Huang wrote the article.

Conflicts of Interest: The authors declare no conflict of interest.

\section{References}

1. Dahmann, C.; Oates, A.C.; Brand, M. Boundary formation and maintenance in tissue development. Nat. Rev. Genet. 2011, 12, 43-55. [CrossRef] [PubMed] 
2. Zadnikova, P.; Simon, R. How boundaries control plant development. Curr. Opin. Plant Biol. 2014, 17, 116-125. [CrossRef] [PubMed]

3. Hepworth, S.R.; Pautot, V.A. Beyond the divide: Boundaries for patterning and stem cell regulation in plants. Front. Plant Sci. 2015, 6, 1052. [CrossRef] [PubMed]

4. Sablowski, R. Control of patterning, growth, and differentiation by floral organ identity genes. J. Exp. Bot. 2015, 66, 1065-1073. [CrossRef] [PubMed]

5. Takada, S.; Hibara, K.; Ishida, T.; Tasaka, M. The CUP-SHAPED COTYLEDON1 gene of Arabidopsis regulates shoot apical meristem formation. Development 2001, 128, 1127-1135. [PubMed]

6. Vroemen, C.W. The CUP-SHAPED COTYLEDON3 gene is required for boundary and shoot meristem formation in Arabidopsis. Plant Cell 2003, 15, 1563-1577. [CrossRef] [PubMed]

7. Taoka, K.I.; Yanagimoto, Y.; Daimon, Y.; Hibara, K.I.; Aida, M.; Tasaka, M. The NAC domain mediates functional specificity of CUP-SHAPED COTYLEDON proteins. Plant J. 2004, 40, 462-473. [CrossRef] [PubMed]

8. Huang, T.; López-Giráldez, F.; Townsend, J.P.; Irish, V.F. RBE controls microRNA164 expression to effect floral organogenesis. Development 2012, 139, 2161-2169. [CrossRef] [PubMed]

9. Lampugnani, E.R.; Kilinc, A.; Smyth, D.R. PETAL LOSS is a boundary gene that inhibits growth between developing sepals in Arabidopsis thaliana. Plant J. 2012, 71, 724-735. [CrossRef] [PubMed]

10. Ó'Maoiléidigh, D.S.; Graciet, E.; Wellmer, F. Gene networks controlling Arabidopsis thaliana flower development. New Phytol. 2014, 201, 16-30. [CrossRef] [PubMed]

11. Irish, V.F. The flowering of Arabidopsis flower development. Plant J. 2010, 61, 1014-1028. [CrossRef] [PubMed]

12. Barton, M. Twenty years on: The inner workings of the shoot apical meristem, a developmental dynamo. Dev. Biol. 2010, 341, 95-113. [CrossRef] [PubMed]

13. Shapiro, B.E.; Tobin, C.; Mjolsness, E.; Meyerowitz, E.M. Analysis of cell division patterns in the Arabidopsis shoot apical meristem. Proc. Natl. Acad. Sci. USA 2015, 112, 4815-4820. [CrossRef] [PubMed]

14. Aida, M.; Tasaka, M. Morphogenesis and patterning at the organ boundaries in the higher plant shoot apex. Plant Mol. Biol. 2006, 60, 915-928. [CrossRef] [PubMed]

15. Aichinger, E.; Kornet, N.; Friedrich, T.; Laux, T. Plant stem cell niches. Annu. Rev. Plant Biol. 2012, 63, 615-636. [CrossRef] [PubMed]

16. Holt, A.L.; van Haperen, J.M.; Groot, E.P.; Laux, T. Signaling in shoot and flower meristems of Arabidopsis thaliana. Curr. Opin. Plant Biol. 2014, 17, 96-102. [CrossRef] [PubMed]

17. Wigge, P.A.; Kim, M.C.; Jaeger, K.E.; Busch, W.; Schmid, M.; Lohmann, J.U.; Weigel, D. Integration of spatial and temporal information during floral induction in Arabidopsis. Science 2005, 309, 1056-1059. [CrossRef] [PubMed]

18. Sessions, A.; Yanofsky, M.F.; Weigel, D. Cell-cell signaling and movement by the floral transcription factors LEAFY and APETALA1. Science 2000, 289, 779-781. [CrossRef] [PubMed]

19. Wagner, D.; Sablowski, R.W.; Meyerowitz, E.M. Transcriptional activation of APETALA1 by LEAFY. Science 1999, 285, 582-584. [CrossRef] [PubMed]

20. Traas, J.; Doonan, J.H. Cellular basis of shoot apical meristem development. Int. Rev. Cytol. 2001, 208, 161-206. [PubMed]

21. Rast, M.I.; Simon, R. The meristem-to-organ boundary: More than an extremity of anything. Curr. Opin. Genet. Dev. 2008, 18, 287-294. [CrossRef] [PubMed]

22. Murray, J.A.; Jones, A.; Godin, C.; Traas, J. Systems analysis of shoot apical meristem growth and development: Integrating hormonal and mechanical signaling. Plant Cell 2012, 24, 3907-3919. [CrossRef] [PubMed]

23. Aida, M.; Vernoux, T.; Furutani, M.; Traas, J.; Tasaka, M. Roles of PIN-FORMED1 and MONOPTEROS in pattern formation of the apical region of the Arabidopsis embryo. Development 2002, 129, 3965-3974. [PubMed]

24. Vernoux, T.; Kronenberger, J.; Grandjean, O.; Laufs, P.; Traas, J. PIN-FORMED 1 regulates cell fate at the periphery of the shoot apical meristem. Development 2000, 127, 5157-5165. [PubMed]

25. Hay, A.; Barkoulas, M.; Tsiantis, M. ASYMMETRIC LEAVES1 and auxin activities converge to repress BREVIPEDICELLUS expression and promote leaf development in Arabidopsis. Development 2006, 133, 3955-3961. [CrossRef] [PubMed]

26. Schuetz, M.; Berleth, T.; Mattsson, J. Multiple monopteros-dependent pathways are involved in leaf initiation. Plant Physiol. 2008, 148, 870-880. [CrossRef] [PubMed] 
27. Long, J.A.; Moan, E.I.; Medford, J.I.; Barton, M.K. A member of the KNOTTED class of homeodomain proteins encoded by the STM gene of Arabidopsis. Nature 1996, 379, 66-69. [CrossRef] [PubMed]

28. Spinelli, S.V.; Martin, A.P.; Viola, I.L.; Gonzalez, D.H.; Palatnik, J.F. A mechanistic link between STM and CUC1 during Arabidopsis development. Plant Physiol. 2011, 156, 1894-1904. [CrossRef] [PubMed]

29. Aida, M.; Ishida, T.; Tasaka, M. Shoot apical meristem and cotyledon formation during Arabidopsis embryogenesis: Interaction among the CUP-SHAPED COTYLEDON and SHOOT MERISTEMLESS genes. Development 1999, 126, 1563-1570. [PubMed]

30. Byrne, M.E.; Simorowski, J.; Martienssen, R.A. ASYMMETRIC LEAVES1 reveals knox gene redundancy in Arabidopsis. Development 2002, 129, 1957-1965. [PubMed]

31. Belles-Boix, E.; Hamant, O.; Witiak, S.M.; Morin, H.; Traas, J.; Pautot, V. KNAT6: An Arabidopsis homeobox gene involved in meristem activity and organ separation. Plant Cell 2006, 18, 1900-1907. [CrossRef] [PubMed]

32. Jasinski, S.; Piazza, P.; Craft, J.; Hay, A.; Woolley, L.; Rieu, I.; Phillips, A.; Hedden, P.; Tsiantis, M. KNOX action in Arabidopsis is mediated by coordinate regulation of cytokinin and gibberellin activities. Curr. Biol. 2005, 15, 1560-1565. [CrossRef] [PubMed]

33. Yanai, O.; Shani, E.; Dolezal, K.; Tarkowski, P.; Sablowski, R.; Sandberg, G.; Samach, A.; Ori, N. Arabidopsis KNOXI proteins activate cytokinin biosynthesis. Curr. Biol. 2005, 15, 1566-1571. [CrossRef] [PubMed]

34. Bolduc, N.; Hake, S. The maize transcription factor KNOTTED1 directly regulates the gibberellin catabolism gene ga2ox1. Plant Cell 2009, 21, 1647-1658. [CrossRef] [PubMed]

35. Sakamoto, T.; Kamiya, N.; Ueguchi-Tanaka, M.; Iwahori, S.; Matsuoka, M. KNOX homeodomain protein directly suppresses the expression of a gibberellin biosynthetic gene in the tobacco shoot apical meristem. Genes Dev. 2001, 15, 581-590. [CrossRef] [PubMed]

36. Gendron, J.M.; Liu, J.-S.; Fan, M.; Bai, M.-Y.; Wenkel, S.; Springer, P.S.; Barton, M.K.; Wang, Z.-Y. Brassinosteroids regulate organ boundary formation in the shoot apical meristem of Arabidopsis. Proc. Natl. Acad. Sci. USA 2012, 109, 21152-21157. [CrossRef] [PubMed]

37. Tsuda, K.; Kurata, N.; Ohyanagi, H.; Hake, S. Genome-wide study of KNOX regulatory network reveals brassinosteroid catabolic genes important for shoot meristem function in rice. Plant Cell 2014, 26, 3488-3500. [CrossRef] [PubMed]

38. William, D.A.; Su, Y.; Smith, M.R.; Lu, M.; Baldwin, D.A.; Wagner, D. Genomic identification of direct target genes of LEAFY. Proc. Natl. Acad. Sci. USA 2004, 101, 1775-1780. [CrossRef] [PubMed]

39. Yamaguchi, N.; Wu, M.-F.; Winter, C.M.; Berns, M.C.; Nole-Wilson, S.; Yamaguchi, A.; Coupland, G.; Krizek, B.A.; Wagner, D. A molecular framework for auxin-mediated initiation of flower primordia. Dev. Cell 2013, 24, 271-282. [CrossRef] [PubMed]

40. Winter, C.M.; Austin, R.S.; Blanvillain-Baufume, S.; Reback, M.A.; Monniaux, M.; Wu, M.-F.; Sang, Y.; Yamaguchi, A.; Yamaguchi, N.; Parker, J.E. LEAFY target genes reveal floral regulatory logic, cis motifs, and a link to biotic stimulus response. Dev. Cell 2011, 20, 430-443. [CrossRef] [PubMed]

41. Smith, H.M.; Campbell, B.C.; Hake, S. Competence to respond to floral inductive signals requires the homeobox genes PENNYWISE and POUND-FOOLISH. Curr. Biol. 2004, 14, 812-817. [CrossRef] [PubMed]

42. Kanrar, S.; Bhattacharya, M.; Arthur, B.; Courtier, J.; Smith, H. Regulatory networks that function to specify flower meristems require the function of homeobox genes PENNYWISE and POUND-FOOLISH in Arabidopsis. Plant J. 2008, 54, 924-937. [CrossRef] [PubMed]

43. Ung, N.; Lal, S.; Smith, H.M. The role of PENNYWISE and POUND-FOOLISH in the maintenance of the shoot apical meristem in Arabidopsis. Plant Physiol. 2011, 156, 605-614. [CrossRef] [PubMed]

44. Khan, M.; Ragni, L.; Tabb, P.; Salasini, B.C.; Chatfield, S.; Datla, R.; Lock, J.; Kuai, X.; Després, C.; Proveniers, M. Repression of lateral organ boundary genes by PENNYWISE and POUND-FOOLISH is essential for meristem maintenance and flowering in Arabidopsis thaliana. Plant Physiol. 2015, 169, 2166-2186. [PubMed]

45. Lal, S.; Pacis, L.B.; Smith, H.M. Regulation of the SQUAMOSA PROMOTER-BINDING PROTEIN-LIKE genes/microRNA156 module by the homeodomain proteins PENNYWISE and POUND-FOOLISH in Arabidopsis. Mol. Plant 2011, 4, 1123-1132. [CrossRef] [PubMed]

46. Lee, I.; Wolfe, D.S.; Nilsson, O.; Weigel, D. A LEAFY co-regulator encoded by UNUSUAL FLORAL ORGANS. Curr. Biol. 1997, 7, 95-104. [CrossRef] 
47. Samach, A.; Klenz, J.E.; Kohalmi, S.E.; Risseeuw, E.; Haughn, G.W.; Crosby, W.L. The UNUSUAL FLORAL ORGANS gene of Arabidopsis thaliana is an F-box protein required for normal patterning and growth in the floral meristem. Plant J. 1999, 20, 433-445. [CrossRef] [PubMed]

48. Levin, J.Z.; Meyerowitz, E.M. UFO: An Arabidopsis gene involved in both floral meristem and floral organ development. Plant Cell 1995, 7, 529-548. [CrossRef] [PubMed]

49. Wilkinson, M.D.; Haughn, G.W. UNUSUAL FLORAL ORGANS controls meristem identity and organ primordia fate in Arabidopsis. Plant Cell 1995, 7, 1485-1499. [CrossRef] [PubMed]

50. Risseeuw, E.; Venglat, P.; Xiang, D.; Komendant, K.; Daskalchuk, T.; Babic, V.; Crosby, W.; Datla, R. An activated form of UFO alters leaf development and produces ectopic floral and inflorescence meristems. PLoS ONE 2013, 8, e83807. [CrossRef] [PubMed]

51. Chae, E.; Tan, Q.K.-G.; Hill, T.A.; Irish, V.F. An Arabidopsis F-box protein acts as a transcriptional co-factor to regulate floral development. Development 2008, 135, 1235-1245. [CrossRef] [PubMed]

52. Zhao, Y.; Medrano, L.; Ohashi, K.; Fletcher, J.C.; Yu, H.; Sakai, H.; Meyerowitz, E.M. HANABA TARANU is a gata transcription factor that regulates shoot apical meristem and flower development in Arabidopsis. Plant Cell 2004, 16, 2586-2600. [CrossRef] [PubMed]

53. Ding, L.; Yan, S.; Jiang, L.; Zhao, W.; Ning, K.; Zhao, J.; Liu, X.; Zhang, J.; Wang, Q.; Zhang, X. HANABA TARANU (HAN) bridges meristem and organ primordia boundaries through PINHEAD, JAGGED, BLADE-ON-PETIOLE2 and CYTOKININ OXIDASE3 during flower development in Arabidopsis. PLOS Genet. 2015, 11, e1005479. [CrossRef] [PubMed]

54. Liu, Q.; Yao, X.; Pi, L.; Wang, H.; Cui, X.; Huang, H. The ARGONAUTE10 gene modulates shoot apical meristem maintenance and establishment of leaf polarity by repressing miR165/166 in Arabidopsis. Plant J. 2009, 58, 27-40. [CrossRef] [PubMed]

55. Ji, L.; Liu, X.; Yan, J.; Wang, W.; Yumul, R.E.; Kim, Y.J.; Dinh, T.T.; Liu, J.; Cui, X.; Zheng, B.; et al. ARGONAUTE10 and ARGONAUTE1 regulate the termination of floral stem cells through two microRNAs in Arabidopsis. PLoS Genet. 2011, 7, e1001358. [CrossRef] [PubMed]

56. Zhu, H.; Hu, F.; Wang, R.; Zhou, X.; Sze, S.-H.; Liou, L.W.; Barefoot, A.; Dickman, M.; Zhang, X. Arabidopsis ARGONAUTE10 specifically sequesters miR166/165 to regulate shoot apical meristem development. Cell 2011, 145, 242-256. [CrossRef] [PubMed]

57. Ohno, C.K.; Reddy, G.V.; Heisler, M.G.; Meyerowitz, E.M. The Arabidopsis JAGGED gene encodes a zinc finger protein that promotes leaf tissue development. Development 2004, 131, 1111-1122. [CrossRef] [PubMed]

58. Dinneny, J.R.; Yadegari, R.; Fischer, R.L.; Yanofsky, M.F.; Weigel, D. The role of JAGGED in shaping lateral organs. Development 2004, 131, 1101-1110. [CrossRef] [PubMed]

59. Ha, C.M.; Jun, J.H.; Nam, H.G.; Fletcher, J.C. BLADE-ON-PETIOLE 1 and 2 control Arabidopsis lateral organ fate through regulation of LOB domain and adaxial-abaxial polarity genes. Plant Cell 2007, 19, 1809-1825. [CrossRef] [PubMed]

60. Hepworth, S.R.; Zhang, Y.; McKim, S.; Li, X.; Haughn, G.W. BLADE-ON-PETIOLE-dependent signaling controls leaf and floral patterning in Arabidopsis. Plant Cell 2005, 17, 1434-1448. [CrossRef] [PubMed]

61. Aida, M.; Ishida, T.; Fukaki, H.; Fujisawa, H.; Tasaka, M. Genes involved in organ separation in Arabidopsis: An analysis of the cup-shaped cotyledon mutant. Plant Cell 1997, 9, 841-857. [CrossRef] [PubMed]

62. Cho, E.; Zambryski, P.C. Organ boundary1 defines a gene expressed at the junction between the shoot apical meristem and lateral organs. Proc. Natl. Acad. Sci. USA 2011, 108, 2154-2159. [CrossRef] [PubMed]

63. Takeda, S.; Hanano, K.; Kariya, A.; Shimizu, S.; Zhao, L.; Matsui, M.; Tasaka, M.; Aida, M. CUP-SHAPED COTYLEDON1 transcription factor activates the expression of LSH4 and LSH3, two members of the ALOG gene family, in shoot organ boundary cells. Plant J. 2011, 66, 1066-1077. [CrossRef] [PubMed]

64. Koyama, T.; Furutani, M.; Tasaka, M.; Ohme-Takagi, M. TCP transcription factors control the morphology of shoot lateral organs via negative regulation of the expression of boundary-specific genes in Arabidopsis. Plant Cell 2007, 19, 473-484. [CrossRef] [PubMed]

65. Koyama, T.; Mitsuda, N.; Seki, M.; Shinozaki, K.; Ohme-Takagi, M. TCP transcription factors regulate the activities of ASYMMETRIC LEAVES1 and miR164, as well as the auxin response, during differentiation of leaves in Arabidopsis. Plant Cell 2010, 22, 3574-3588. [CrossRef] [PubMed]

66. Laufs, P.; Peaucelle, A.; Morin, H.; Traas, J. MicroRNA regulation of the CUC genes is required for boundary size control in Arabidopsis meristems. Development 2004, 131, 4311-4322. [CrossRef] [PubMed] 
67. Baker, C.C.; Sieber, P.; Wellmer, F.; Meyerowitz, E.M. The early extra petals1 mutant uncovers a role for microRNA miR164c in regulating petal number in Arabidopsis. Curr. Biol. 2005, 15, 303-315. [CrossRef] [PubMed]

68. Wang, X.-J.; Reyes, J.L.; Chua, N.-H.; Gaasterland, T. Prediction and identification of Arabidopsis thaliana microRNAs and their mRNA targets. Genome Biol. 2004, 5, R65. [CrossRef] [PubMed]

69. Mallory, A.C.; Dugas, D.V.; Bartel, D.P.; Bartel, B. MicroRNA regulation of NAC-domain targets is required for proper formation and separation of adjacent embryonic, vegetative, and floral organs. Curr. Biol. 2004, 14, 1035-1046. [CrossRef] [PubMed]

70. Krizek, B.A.; Lewis, M.W.; Fletcher, J.C. RABBIT EARS is a second-whorl repressor of AGAMOUS that maintains spatial boundaries in Arabidopsis flowers. Plant J. 2006, 45, 369-383. [CrossRef] [PubMed]

71. Takeda, S.; Matsumoto, N.; Okada, K. RABBIT EARS, encoding a SUPERMAN-like zinc finger protein, regulates petal development in Arabidopsis thaliana. Development 2004, 131, 425-434. [CrossRef] [PubMed]

72. Lampugnani, E.R.; Kilinc, A.; Smyth, D.R. Auxin controls petal initiation in Arabidopsis. Development 2013, 140, 185-194. [CrossRef] [PubMed]

73. González-Carranza, Z.H.; Rompa, U.; Peters, J.L.; Bhatt, A.M.; Wagstaff, C.; Stead, A.D.; Roberts, J.A. HAWAIIAN SKIRT: An F-box gene that regulates organ fusion and growth in Arabidopsis. Plant Physiol. 2007, 144, 1370-1382. [CrossRef] [PubMed]

74. Levin, J.Z.; Fletcher, J.C.; Chen, X.; Meyerowitz, E.M. A genetic screen for modifiers of UFO meristem activity identifies three novel FUSED FLORAL ORGANS genes required for early flower development in Arabidopsis. Genetics 1998, 149, 579-595. [PubMed]

75. Bowman, J.L.; Sakai, H.; Jack, T.; Weigel, D.; Mayer, U.; Meyerowitz, E.M. SUPERMAN, a regulator of floral homeotic genes in Arabidopsis. Development 1992, 114, 599-615. [PubMed]

76. Sakai, H.; Medrano, L.J.; Meyerowitz, E.M. Role of SUPERMAN in maintaining Arabidopsis floral whorl boundaries. Nature 1995, 378, 199-203. [CrossRef] [PubMed]

77. Sakai, H.; Krizek, B.A.; Jacobsen, S.E.; Meyerowitz, E.M. Regulation of SUP expression identifies multiple regulators involved in Arabidopsis floral meristem development. Plant Cell 2000, 12, 1607-1618. [CrossRef] [PubMed]

78. Nibau, C.; Di Stilio, V.S.; Wu, H.-M.; Cheung, A.Y. Arabidopsis and Tobacco SUPERMAN regulate hormone signalling and mediate cell proliferation and differentiation. J. Exp. Bot. 2011, 62, 949-961. [CrossRef] [PubMed]

79. Furey, T.S. ChIP-seq and beyond: New and improved methodologies to detect and characterize protein-DNA interactions. Nat. Rev. Genet. 2012, 13, 840-852. [CrossRef] [PubMed]

80. Wang, Y.; Sun, S.; Zhu, W.; Jia, K.; Yang, H.; Wang, X. STRIGOLACTONE/MAX2-induced degradation of brassinosteroid transcriptional effector BES1 regulates shoot branching. Dev. Cell 2013, 27, 681-688. [CrossRef] [PubMed]

81. Stegmann, M.; Anderson, R.G.; Ichimura, K.; Pecenkova, T.; Reuter, P.; Zarsky, V.; McDowell, J.M.; Shirasu, K.; Trujillo, M. The ubiquitin ligase PUB22 targets a subunit of the exocyst complex required for PAMP-triggered responses in Arabidopsis. Plant Cell 2012, 24, 4703-4716. [CrossRef] [PubMed]

82. Nardiello, D.; Palermo, C.; Natale, A.; Quinto, M.; Centonze, D. Strategies in protein sequencing and characterization: Multi-enzyme digestion coupled with alternate CID/ETD tandem mass spectrometry. Anal. Chim. Acta 2015, 854, 106-117. [CrossRef] [PubMed]

83. Tian, C.; Zhang, X.; He, J.; Yu, H.; Wang, Y.; Shi, B.; Han, Y.; Wang, G.; Feng, X.; Zhang, C. An organ boundary-enriched gene regulatory network uncovers regulatory hierarchies underlying axillary meristem initiation. Mol. Syst. Biol. 2014, 10, 755. [CrossRef] [PubMed]

84. Chandler, J.W.; Werr, W. Cytokinin-auxin crosstalk in cell type specification. Trends Plant Sci. 2015, 20, 291-300. [CrossRef] [PubMed]

85. Vernoux, T.; Besnard, F.; Traas, J. Auxin at the shoot apical meristem. Cold Spring Harb. Perspect. Biol. 2010, 2, a001487. [CrossRef] [PubMed]

86. Shimizu, T.; Miyakawa, S.; Esaki, T.; Mizuno, H.; Masujima, T.; Koshiba, T.; Seo, M. Live single cell plant hormone analysis by video-mass spectrometry. Plant Cell Physiol. 2015. [CrossRef] [PubMed]

87. Walton, A.; Stes, E.; Smet, I.; Goormachtig, S.; Gevaert, K. Plant hormone signalling through the eye of the mass spectrometer. Proteomics 2015, 15, 1113-1126. [CrossRef] [PubMed] 
88. Ulmasov, T.; Murfett, J.; Hagen, G.; Guilfoyle, T.J. Aux/IAA proteins repress expression of reporter genes containing natural and highly active synthetic auxin response elements. Plant Cell 1997, 9, 1963-1971. [CrossRef] [PubMed]

89. Brunoud, G.; Wells, D.M.; Oliva, M.; Larrieu, A.; Mirabet, V.; Burrow, A.H.; Beeckman, T.; Kepinski, S.; Traas, J.; Bennett, M.J. A novel sensor to map auxin response and distribution at high spatio-temporal resolution. Nature 2012, 482, 103-106. [CrossRef] [PubMed]

90. Shani, E.; Weinstain, R.; Zhang, Y.; Castillejo, C.; Kaiserli, E.; Chory, J.; Tsien, R.Y.; Estelle, M. Gibberellins accumulate in the elongating endodermal cells of Arabidopsis root. Proc. Natl. Acad. Sci. USA 2013, 110, 4834-4839. [CrossRef] [PubMed]

91. Irani, N.G.; Di Rubbo, S.; Mylle, E.; Van den Begin, J.; Schneider-Pizoń, J.; Hniliková, J.; Š́́ša, M.; Buyst, D.; Vilarrasa-Blasi, J.; Szatmári, A.-M. Fluorescent castasterone reveals BRI1 signaling from the plasma membrane. Nat. Chem. Biol. 2012, 8, 583-589. [CrossRef] [PubMed]

(C) 2016 by the authors; licensee MDPI, Basel, Switzerland. This article is an open access article distributed under the terms and conditions of the Creative Commons by Attribution (CC-BY) license (http://creativecommons.org/licenses/by/4.0/). 